\title{
American Studies as a Set of Discourses
}

\author{
By David E. Nye
}

University of Odense

Since its inception American Studies has been uneasy with methodology. ${ }^{1}$ Many have demanded that it establish a single method, and their suggestions almost invariably favor the home discipline of the proposer. Yet because it is an interdisciplinary fraternity, with no single group of gatekeepers that determine who is a member, American Studies continues to be a crossroads where many disciplines meet rather than a territory staked out and protected by methodological boundaries. In this paper, I will begin with a few observations about text and context, with particular reference to the relations between history and literature. Second, I will examine three different traditions in American Studies as examples of how its practitioners have understood text and context. Third, I will suggest how these three traditions can profit from confrontations with some recent European theories.

American Studies has always been concerned with history and literature, and with the problem of how to read documents. At an early age we may read naively, taking a novel to be a direct transcription of reality. Later we see that there are some difficulties in moving from the world to the book and back again. The book does not stencil the world. Teachers often find that before they can discuss novels with students they must demonstrate that fiction is not purely mimetic. Yet these same teachers may speak rather freely about the historical context of a work, as though history were a comfortable solidity, a certainty against which the literary work shimmers in all its ambiguities and contradictions. But history is little more certain or solid than literature. The historian builds up a narrative based on thousands of incomplete documents. These documents come in no predetermined order, and there is little reason to believe that a story constructed from them offers the literary critic an unproblematic background.

The more closely I read history, the less confident I am about what happened in the past. Yet I am not willing to grant that history is vir- 
tually the same as fiction. I know that some things could not have happened. Martin Luther did not drive an automobile. Thomas Jefferson was not President after Andrew Jackson. Life expectancy in medieval England was lower than at present. If establishing the context of a literary work means identifying which machines existed at the time, or who ruled, or how long people usually lived, then history seems able to provide that context. From these examples it might seem that the problem of writing history is not one of determining facts but rather that of assembling them into narratives. But the so-called "facts" often become problematic. For example, Gary Wills has challenged the "fact" that Thomas Jefferson based the American Declaration of Independence on the philosophy of John Locke, instead arguing that the Scottish moral philosophers of the early eighteenth century provided the framework for that document. 2

Note that in this example I have shifted from the material level automobiles, sequences of rulers, and life expectancy - to questions of what was thought or felt in the past. For the purposes of this brief paper, I would like to distinguish between two kinds of historical context, the material and the intellectual. (This distinction does not correspond to that between base and superstructure.) By material context I refer to surviving physical fragments of the past such as artifacts and buildings; by intellectual context I refer to what it meant to make, use, or own such artifacts or buildings. The manuscript of a novel and its subsequent editions are part of the material context, but the writing and the reading of the novel are part of the intellectual context. History which focuses exclusively on the material context cannot tell a story; it can only establish a rough sequence. This sequence, potentially limitless and therefore hypothetical, includes everything known about the past without making distinctions between the items on the list. In other words, it is an undifferentiated chronology. Once the historian selects elements to form a series and links these in an argument, he or she has begun to create a narrative.

As Hayden White has put it,

... the presumed concreteness and accessibility of historical milieux, these contexts of the texts that literary critics study, are themselves the products of the fictive capabilities of the historians.

Nor does rewriting history make the past more solid and graspable:

Each new historical work only adds to the number of possible texts that have to be interpreted if a full and accurate picture of a given historical milieu is to be faithfully drawn. The relationship between the past to be analyzed and historical works pro- 
duced by analysis of the documents is paradoxical; the more we know about the past, the more difficult it is to generalize about it. ${ }^{3}$

The "background" that some literary critics seek is an unstable mixture of documents from the material context continually being reinterpreted as parts of various intellectual contexts.

With these observations in mind, consider the position of American Studies. It has been preoccupied by internal debates about method, and development has occurred without much overt reference to the European dialogues called "structuralism and post-structuralism." Only in the 1980s, has the field begun to come to terms with recent Continental thought. ${ }^{4}$ Yet any practitioner in American Studies may be understandably wary of these theories. The first structuralist writings adopted an oversimplified theory of language from Ferdinand de Saussure, and they developed a semiotics far less subtle than that of Charles Sanders Pierce. The years of debate among Claude Levi-Strauss, Jacques Derrida, Jacques Lacan, Roland Barthes, and Michel Foucault, to mention only a few, would seem to suggest that no new method is at hand, and that the wise course might be to practice eclecticism, taking bits of theories and piecing together an approach to any project as best one can. 5 The "structuralist revolution" offers more than an engaging eclecticism, however, for it can lead to a reconsideration of "the search for method in American Studies" that has continued now for more than thirty years.

Given its interdisciplinary organization, American Studies scholars probably could never adopt a single method in order to achieve definition as a field, but they could recognizethis multiplicity as an advantage. They possess many simultaneous discourses, and that diversity could be enhanced. Abandoning internal debates aimed at developing a single method, the field could reconceive itself as an anti-discipline, attacking the practice of integrating theories into a totality.

In such a reorientation of American Studies, Hayden White's Metahistory can be extremely useful. ${ }^{6}$ White examines the works of major nineteenth-century European historians (Michelet, Tocqueville, Ranke, Burkhardt, Marx, and Croce) to exemplify how "the historicalimagination" employs different forms of narrative. He contends that historical narratives are verbal models created because the material context does not provide "an unambiguous image of the structure of events." The historian cannot create a hypothesis and then test it against a knowable past "reality." Rather, 
In order to figure "what really happened" in the past ... the historian must first prefigure as a possible object of knowledge the whole set of events reported in the documents. This prefigurative act is poetic inasmuch as it is precognitive and precritical in the economy of the historian's own consciousness. It is also poetic insofar as it is constitutive of the structure that will subsequently be imaged in the verbal model offered by the historian as a representation of "what really happened" in the past ... In the poetic act which precedes the formal analysis of the field, the historian both creates his object of analysis and predetermines the modality of the conceptual strategies he will use to explain it. ${ }^{7}$

In Metahistory White harnesses this basic insight to his own "prefigurement" of history as a possible object of knowledge by combining Northrup Frye's poetics, Stephen Pepper's World Hypotheses, and Kenneth Burke's rhetorical analysis. I am not entirely comfortable with the way White then argues that historians choose between four kinds of possible argument, four possible ideological stances, and again four tropess. ${ }^{8}$ The recurrence of these quartets seems too pat. But White's kernel insight must not be dismissed because his development of it seems too symmetrical. Surely he is correct: every historian begins writing with a poetic prefigurement of the segment of the past to be examined.

Those who write about method in American Studies have prefigured its history as one of flawed approaches whose defects can be remedied. They assume at the outset that a correct method can be found. Instead, the field (or indeed any focus of study) can be understood as a site where discourses interpenetrate. Any open site in the academic world necessarily displays contradictions between methods, including competing ways to conceptualize the relationship between text and context. I will examine three in American Studies: the "myth and symbol school," the "new social hisory," and the "Kuhnian historians."

Leo Marx's The Machine in the Garden: Technology and the Pastoral ideal in America'(1964)provides an example of the "myth and symbol school."9 Marx wrote a history of American literature not in the manner of the New Critics, who viewed literature as an autonomous system, or of the biographical critics, who treated it as an extension of intellectual history. Instead, Marx saw literature as a form of mythology that formalizes a culture's ideas about the world. In the United States, the pastoral ideal has been a governing idea both in politics and in literature; to write about it required a broad definition of what could be included as texts in the analysis of literature. The Machine in the Garden included Congressional reports on manufacturing, political speeches, entries in notebooks, oil paintings, and geographicaldescriptions as well as poetry and fiction. As Marx himself put it, 
In this passage, Marx touches directly on the theme of text and context, suggesting one solution to the problem of their relationship. He conceives of literature broadly, giving special attention to "the region of culture" where literary works meet the "general ideas" produced by the "collective imagination." Marx is most concerned with the "general idea" of pastoralism, and he spends considerable space defining it, as a literary trope first developed in ancient Greece and Rome, as a popular, sentimental idea, and as a complex form in American literature. The focus of Marx's book is neither literature nor intellectual history, but rather the pastoral ideal itself. Thus, rather than work with a simple dichotomy between literary texts and their social context, Marx interposed a third term between them, a "region of culture where literature, general ideas, and certain products of the collective imagination" meet. In this "region" are located the "cultural symbols" and "myths" that give the culture coherence. Most importantly, Marx conceived of these myths and symbols as being internally contradictory, expressing and apparently resolving cultural problems.

Marx was not alone in conceiving of American culture in this way; his book was a culmination of developments that had begun in the late 1940s, when his mentors, F. O. Matthiessen and Henry Nash Smith, devised the elements of this model of culture. 11 While we might wish that they had spent more time defining the central terms, "myth" and "symbol," there can be no question that they offered one approach to the problem of the relation of texts to their context. Marx has never evinced any interest in developing his work in the direction of semiotics or structuralism, although these approaches might seem to have affinities with his. Instead, he has defended a humanistic, non-scientific approach to American Studies, and despite Cecil Tate's book length analysis of the "myth and symbol" tradition that called for an overt marriage between it and structuralism, early practitioners of that school have not taken up the suggestion. ${ }^{12}$

Marx faced considerable opposition within American Studies, even as his book became influential. He was attacked in an article that appeared in The American Quarterly (1972) by Bruce Kuklick who was then about to take over that journal as editor. ${ }^{13}$ Kuklick conceived of the relationship of text and context quite differently than Marx. For him, 
imaginative literature played a much smaller role in defining culture than did the material processes of history. Kuklick championed the methods of the "new" social historians, who in the middle 1960s had begun to produce works emphasizing the common people of the past and their daily lives. For them and for Kuklick, literature and the arts were far less central in the formation and maintenance of culture than they had been for Marx.

The social historians were sophisticated in their discovery of source materials, learning much from the French annales school and developing computer programs for the analysis of neglected documents. But these same historians were more naive than Marx when it came to writing narrative. However new their methods, they took a traditional view of documents: they were "sources" from which one might construct descriptions of the past. The social historians took little interest in literary and artistic works, since these reflected the views of a social elite. For them, a document was not flawed due to some deficiency of language itself, as Derrida argues, but due to the inevitable biases of class, wealth, and social privilege. They likewise paid scant attention to the narrative form of their own works. Like the annalistes they wrote analysis without being dramatic or novelistic.

Stephen Thernstrom's study of Poverty and Progress in a nineteenth century manufacturing town exemplifies the work of this group. ${ }^{14}$ Working from bank records, town directories, and other such records, Thernstrom painstakingly reconstructed the modest economic progress of the lower class through three generations. He portrayed the lives of an inarticulate group, not through the written texts familiar to literary scholars, but through the regularities he discovered in group behavior and experience. In his work, the individual text could mean but little, taking on significance only once it had been assimilated to a larger class of phenomena. Others imitated Thernstrom's widely praised book, and this "new social history" attracted many in American Studies.

Despite their emphasis on patterns and regularities, however, the social historians failed to create an overarching vision of American history. Their books tended to focus exclusively on single communities or groups, such as the working class in a Massachusetts town, a farming area in southern Pennsylvania, or the workers in one industry. ${ }^{15}$ Such specialization soon led to fragmentation, because there was little to link the many pieces. Gordon Wood commented in the New York Review of Books that in the "new social history," 
There is no coherence, there are no central organizing principles, no theme or stories - no narratives - to hold the pieces together. Like some vast protoplasm that divides and sub-divides again and again, history at present seems to be in the process of self-destruction. 16

In the "new social history" every group and community moves through time according to its own particular rhythms, so that the periodizations of women's history, immigrant history, labor history, and technological history, to take but four versions, become irreconcilable. A more comprehensive prefiguration of history as a whole is necessary to connect these many sub-fields.

Scholars adopted many different models to unify work in American Studies, but space permits reference to but one, that which Thomas Kuhn developed in The Structure of Scientific Revolutions. ${ }^{17}$ If the social historians lack structure, the Kuhnian historians may have too much structure. They operate with an elaborate model that presents history as a double set of sequences. The first of these is a sequence each paradigm goes through internally: a core development of an idea or invention, followed by its exploitation, functional consequences and so forth, until it has reached a point of exhaustion. Then comes the second, external sequence, as another paradigm displaces the first.

David W. Noble and Gene Wise championed this approach, although Kuhn himself did not encourage extension of his theory to other fields. ${ }^{18}$ One of the best known recent applications of his model to American history is Anthony F.G. Wallace's Rockdale: The Growth of an American Village in the Early Industrial Revolution. Wallace studied one small town which harnassed water power to textile factories in the first half of the nineteenth century. Using the community oriented approach of social history and of his home discipline, anthropology, he might have been expected to produce one more narrow study, difficult to link with any larger pattern. But by using Kuhn's work Wallace prefigured the ground of his investigation in a new way. Broadening the model, Wallace argued that many (but not all) cultural innovations occur as sequences in five stages: innovation, paradigmatic core development, exploitation, functional consequences, and rationalization. ${ }^{19}$ Wallace began to see the need for such a model when he "realized that Rockdale was one of a number of similar villages where the Industrial Revolution began in the United States and that a standard process of cultural and social change was probably common to all of them. "20 Wallace did not argue that a new technology such as mechanized textile production always led to a "standard process of cultural and social change." The crucial stage in his model, as in Kuhn's, is "paradigmatic core development." To take 
a well-known example, the invention of gun powder in ancient China did not lead to'a redefinition of warfare, with new weapons and defense systems. Gun powder only went through an early "core development" in the West, leading to a "standard process of social and cultural change." Similarly, the availability of new forms of textile machinery would not necessarily change the economy of the United States, but because a "paradigmatic core development" did take place in textiles an industrial revolution began.

Once created, this paradigmatic core develops "according to its own inner law." As one mechanical innovation leads to another, the new technology redefines the work place, changes social relations in the community, and ultimately affects the description of the world offered by religion and politics. The exploitation of new technology thus had unavoidable functional consequences. In Rockdale it created a new set of class relations, it linked the local economy to changes in the international market place, it required that local manufacturers keep abreast of innovations in the rest of the United States and Europe, and it created an environment favorable to religious millennialism. Wallace had established more than a framework for his narrative; he had created a hierarchy within social history in which technology took the key position. In effect, a new technological system is a meta-text that intrudes into the world, creating new social contexts.

To emphasize this social effect, Wallace does not tell his story chronologically, but begins in 1850 , when the new technology has already performed this transformation and Rockdale is a manufacturing community. Only after describing this world does he go back to the preindustrial way of life that preceded it, the incursion of new technologies into that world, and the struggle between social classes for control of those technologies. This dramatic organization makes Rockdale an engrossing story to read, and Wallace heightens the interest by writing in an almost novelistic style. The book begins:

There is a village in America called Rockdale where the people used to manufacture cotton cloth. It lies along the banks of Chester Creek in Delware Country, in southeastern Pennsylvania, between Philadelphia and Wilmington. None of the people who worked in the first cotton mills is alive anymore, but some of their children's children still live there, and the ruins of stone factories, as well as stone tenements and fine stone mansions, are yet standing. ${ }^{21}$

This passage could be "mistaken" for fiction. On the same page, Wallace writes: "I sometimes feel that I can almost reach out and touch the people I have come to know from the letters and diaries and ledgers..." In the first chapters, he looks at Rockdale with "a sentimental, 
even romantic eye" during a "few brief years of relative equilibrium. "22 Later he will describe the turbulent decades of unrest that preceded this equilibrium, and how the Civil War soon disrupted it. Throughout, Wallace writes as a mediator between the reader and a past that he seeks to save from oblivion. In the final pages he evokes the town of the present, where "each year less and less information is left of a world that was once as rich and real as the one that is there today."23 Such sentences suggest how Wallace positions himself between the past and present as an interpreter capable of moving from diaries and letters back to the persons who wrote them. Unlike the social historians, who try to deny narration in favor of pure analysis, Wallace embraces novelistic techniques. The underlying Kuhnian model provides him with an analytical structure and a narrative form.

In comparing these three American Studies traditions, bear in mind that they coexist today and have not replaced one another. The "myth and symbol" critics brought to the field literary training that lead them to approach historical documents as problematic objects that could not be taken at face value. As a group, they have expanded the range of American Studies subjects, including such matters as the public perception of architectural works, the reputations of heroes, or the symbolic meanings of public events. ${ }^{24}$ They read texts to reconstruct a framework of cultural values that once mediated between those texts and their audiences. Underlying this enterprise is an organic conception of culture: the "myth and symbol school" treats symbols as a cultural shorthand, which compresses conflicting ideas, values, and expectations into legibility.

The social historians approach the American past far differently, because they assume that the documentation easily available is grossly incomplete, having been created by the educated and privileged. They want to give a voice to the common people of the past, and generally they do not give much attention to literature and the arts. For them, the historian's role is to rescue and reassemble the hidden parts of the past, creating a new history. This goal runs afoul of the intensely empirical methods they pursue, however, which emphasize community studies. Their empiricism leads to detailed stories which they have not assembled into a larger narrative.

A third group has adopted general models of social change. The models available vary greatly, and here I have examined only one, the Kuhnian model of scientific revolution. This essentially mechanistic approach integrates discrete phenomena in terms of specific classes and laws. The individual text serves as an example rather than as a source, 
as description rather than explanation or exemplification. The text becomes part of a hierarchy where it has less importance than the class or system to which it belongs, and serves as the raw material needed to discern a general law.

Those familiar with American Studies could easily add other approaches to these three, such as the Marxist historiography of William Appleman Williams. ${ }^{25}$ But however long the list, what should be done? Must the historian choose one approach? My answer is no. As soon as one moves from chronology to narrative, the principles of document selection and the form of argument can never be laid down with finality. Historians must always prefigure the ground of their investigations in a poetic act of the imagination. Innovative works emerge whenever several discourses collide and make possible a new prefiguration of an area.

From this perspective the worst thing that scholars in a discipline can do is to embrace an orthodoxy. While many believe that collective agreements on research agendas must precede significant work, I would argue instead that important work emerges from open contradictions between scholarly methods. In order to encourage such contradictions, I would like to draw attention to interpretive traditions that have affinities with the three American Studies method discussed above. I do not suggest that American Studies scholars adopt any of these wholesale, but rather that they could profit from a dialogue with them.

The "myth and symbol school" deals with the text as an articulated whole. It could gain a new dimension by exploring Pierre Macherey's attack on the idea of organic coherence, an idea that underpins the myth and symbol approach. Macherey emphasizes the silences in the text, arguing that every text is incomplete in its very nature. The cultural critic must seek the ideological cause of its incompleteness. This view of the text preserves the school's emphasis on contradictions between symbols; while providing a new conceptualization of context. It would perhaps not be difficult for myth and symbol critics to agree with Macherey that:

... a true analysis does not remain within its object paraphrasing what has already been said; analysis confronts the silences, the denials and the resistance in the object - not that compliant implied discourse which offers itself to discovery but that condition which makes the work possible, which preceds the work so absolutely that it cannot be found in the work. ${ }^{26}$

Macherey views context as a shaping and disruptive structure that at once sustains and distorts the text. His thought is far more amenable to 
the myth and symbol approach than Levi-Strauss's structuralism, which both have rejected on similar grounds. ${ }^{27}$

A few social historians have already begun a dialogue with the works of Michel Foucault. ${ }^{28}$ Both view history as the story of regularities that override individual variations. But where the social historians see groups as the actors in the past, Foucault emphasizes the elaboration of codes, so that history becomes a product of the interplay of signs. The Americans emphasize process, development, cause and effect; Foucault sees history in terms of discursive formations, ensembles of signs, and binary oppositions. If the social historians lack an overarching theory to connect their specialized studies, Foucault often writes with too little regard for the documentary record (in the sense of the material context) and he tends to generalize from a few French documents to a global analysis that is invalid for other societies. Thus while Foucault's studies of medicine and intellectual history can provoke American scholarship because they offer a new prefiguration of history, they must be brought into line with the chronological realities of the American material context. David Rothman's studies of American prisons and insane asylums suggest how the American material context can be remapped along lines Foucault has suggested.29

Finally, Kuhnian historians see such well formed patterns in history that it would be fruitful for them to read the works of Jacques Derrida. Grappling with the theory of deconstruction they would become less certain of their ability to represent the past. Fredric Jameson has remarked that "a theory of models cannot recognize itself for a model without undoing the very premises on which it is itself founded. "30 If the Kuhnian historians recognize their theory as a model that prefigures history rather than as a set of true statements, they will find their work is subject to the objections that Derrida has made to structuralism. Is not the Kuhnian project also the establishment of a privileged metalanguage as the ground of discourse? And isn't such a meta-language suspect in principle?

As these examples suggest, the debates within American Studies may have had the effect of making it parochial. For too long its scholars have sought a single method. It is time to reconceive American Studies as an intellectual crossroads, where documents are not conceived of in terms of foreground and background, primary and secondary, or text and context, but rather as parts of a material context which can be selected from and interpreted according to many prefigurations. And searching for no single method, it will not embrace single interpretations. Instead of seeking to write "definitive works" that reduce their subjects to rigidity, 
American Studies scholars can recall that life is plural, that we each have many selves within us, and that, although materially constricted, we always have a range of choice, in life and in narrative. ${ }^{31}$

\section{NOTES}

1. Guenter H. Lenz discusses "American Studies-Beyond the Crisis? Recent Redefinitions and the Meaning of Theory, History, and Practical Criticism," in Prospects 7, 1983.

2. Gary Wills, Inventing America (New York: Doubleday, 1978).

3. Hayden White, Tropics of Discourse (Baltimore: Johns Hophins, 1978), p. 89.

4. Indeed, American Studies has still expended little intellectual capital on structuralism and the subsequent debates, judging from a look at the most recent issues of its major journals, The American Quarterly, American Studies, Prospects and the Journal of American Studies.

5. The debates among French intellectuals are discussed in Edith Kurzweil's The Age of Structuralism: Lévi-Strauss to Foucault (New York: Columbia University Press, 1980.) On Pierce, see Umberto Eco, A Theory of Semiotics (Bloomington: University of Indiana Press, 1976), pp. 14-16, 68-72.

6. White, Metahistory: The Historical Imagination in Nineteenth Century Europe (Baltimore: Johns Hopkins University Press, 1973).

7. Ibid., pp. 30-31.

8. White himself seems to have backed off from this earlier model. See his "The Question of Narrative in Contemporary Historical Theory," in History and Theory, Winter 1984, pp. 1-33.

9. Leo Marx, The Machine in the Garden (New York: Oxford University Press, 1967).

10. Ibid., p. 4.

11. See FO. Matthiessen, American Renaissance (New York: Oxford University Press, 1941). Henry Nash Smith, Virgin Land (Cambridge: Harvard University Press, 1950).

12. Cecil Tate, The Search for Method in American Studies (Minneapolis: University of Minnesota Press, 1973).

13. Bruce Kuklick, "Myth and Symbol in American Studies," American Quarterly 22 (1970).

14. Stephen Thernstrom, Poverty and Progress (Cambridge: Harvard University Press, 1964).

15. James T. Lemon, The Best Poor Man's Country (Baltimore: Johns Hopkins University Press, 1972). Tamara K. Hareven \& Randolph Langebach's Amoskeag: Life and Work in an American Factory City (New York: Pantheon Books, 1978) is an excellent study of a New England mill town which uses oral history and photographs to create a richly textured image of a community. It contrasts sharply with Wallace's study (discussed below), since it foregrounds the testimony of the workers themselves rather than the historian's model of events.

16. Gordon, S. Wood, "Star Spangled History," The New York Review of Books, Aug. 12, 1982, p. 6.

17. Thomas S. Kuhn, The Structure of Scientific Revolutions(Chicago: University of Chicago Press, 1962). I thank Professor Kuhn for briefly discussing the use of his model in areas outside the history of science, in February, 1982.

18. David W. Noble's Historians Against History (Minneapolis: Minnesota University Press, 1965) was not influenced by Kuhn's theory, but Noble found striking parallels in their work, and he often cited Kuhn's books in lectures. Gene Wise, American Historical Explanations (Minneapolis: Minnesota University Press, 1980 reprint). 
19. Anthony, F. C. Wallace, Rockdale: The Growth of an American Village in the Early Industrial Revolution (New York: W.W. Norton, 1978). The title page contains this summary to the volume's contents: "An account of the coming of the machines, the making of a new way of life in the mill hamlets, the triumph of evangelical capitalists over socialists and infidels, and the transformation of the workers into Christian soldiers in a cotton manufacturing district in Pennsylvania in the years before and during the Civil War."

20. Ihid., p. 477.

21. Ibid., p. 3.

22. Ibid., p. 4.

23. Ibid., p. 473.

24. Alan Trachtenberg, Brooklyn Bridge: Fact and Symbol (Chicago: University of Chicago Press, 1979). David E. Nye, Henry Ford: Ignorant Idealist (Port Washington, New York: Kennikat Press, 1979). John Kasson, Amusing the Million (New York: Hill and Wang, 1976).

25. William Appleman Williams, The Contours of American History (London: Jonathan Cape, 1961).

26. Pierre Macherey, A Theory of Literary Production (London: Routledge \& Kegan Paul, 1978), p. 150.

27. This statement may not hold true for all of those associated with the myth and symbol tradition, but is based upon a conversation with Leo Marx inJanuary 1985, in which he, like Macherey, criticized the structuralist approach to myth as being too positivistic.

28. Michel Foucault, Madness and Civilization (New York: Random House, 1965); The Birth of the Clinic (New York: Pantheon, 1973); Discipline and Punish (New York: Pantheon, 1977).

29. David Rothman, The Discovery of the Asylum: Order and Disorder in the New Republic (Boston: Little Brown, 1971). Conscience and Convenience: The Asylum and its Alternatives in Progressive America (Boston: Little Brown, 1980).

30.Jacques Derrida, Of Grammatology (Baltimore:Johns Hopkins University Press, 1976) is the basic work. FredricJameson, The Prison House of Language (Princeton: Princeton University Press, 1972), p. 208.

31. For two examples of narrative forms that take account of the ideas in this essay, see my The Invented Self: An Anti-biography, from Documents of Thomas A. Edison (Odense, Denmark: Odense University Press, 1983), and Image Worlds: Corporate Identities at General Electric (Cambridge, Mass.: MIT Press, 1985). 